\title{
Recruitment of oyster in artificial collectors on the Amazon macrotidal mangrove coast
}

\section{Izabel Cristina da Silva Almeida Funo ${ }^{*}$ (iD) Ícaro Gomes Antonio ${ }^{2}$ (iD Yllana Ferreira Marinho M $^{3}$ (iD) Josinete Sampaio Monteles ${ }^{1}$ (D) Rodolf Gabriel Prazeres Silva Lopes ${ }^{2}$ (iD) Alfredo Olivera Gálvez ${ }^{4}$ (iD)}

${ }^{1}$ Instituto Federal de Educação, Ciência e Tecnologia (IFMA), 65095-460, Campus São Luís Maracanã, São Luís, MA, Brasil. E-mail: izabelfuno@ifma.edu.br. "Corresponding author.

${ }^{2}$ Centro de Ciências Agrárias, Universidade Estadual do Maranhão (UEMA), São Luís, MA, Brasil

${ }^{3}$ Centro de Ciências Humanas, Naturais, Saúde e Tecnologia, Universidade Federal do Maranhão (UFMA), Pinheiro, MA, Brasil.

${ }^{4}$ Departamento de Pesca e Aquicultura, Universidade Federal Rural de Pernambuco (UFRPE), Recife, PE, Brasil.

\begin{abstract}
The purpose of this study was to determine the moment of the year for the oyster recruitment and define the type of collector and environmental conditions that maximize recruitment. Collections were conducted, during 12 months, on Amazon Macrotidal Mangrove at two different sites: raft (point I) and mangrove (point II). In each location three types of collectors were used (1) transparent PET bottles, (2) green PET bottles, and (3) PVC sheets, each with three replicates. Spats were counted and measured at 45-day intervals, while the environmental data were measured every two weeks. Identification of oyster species occurred by genetic testing (multiplex PCR) by randomly selecting individuals by sampling. Results indicated spat capturing was significantly influenced by the collector type, location and period of collection $(P<0.05$, MANOVA) with significantly higher recruitment in the PVC collector $(P<0.05$, Tukey test). Oyster recruitment occurred throughout the year, suggesting that these individuals reproduce during all months; however, months with less rain and greater salinity were the best for spat collection, while the rainy period with lower salinity proved to be the best for individuals growth. The location in interaction with the environmental variables, mainly salinity, has a significant effect on the recruitment rate of spat and on their size, so that point II (mangrove) had the best results for recruitment and point I (raft) provided the spats of the largest size. Genetic identification verified two native oysters species (Crassostrea gasar and Crassostrea rhizophorae) in both points (I and II).

Key words: mangrove oyster, spat collection, environmental variables.
\end{abstract}

Recrutamento de ostra em coletores artificiais na costa de manguezais de macromaré amazônico

RESUMO: O estudo teve como objetivo determinar o período do ano para coletar sementes de ostras, definir o tipo de coletor e as condições ambientais que maximizam o recrutamento das sementes. As coletas foram conduzidas, durante 12 meses, no manguezal amazonico de macromaré em dois locais distintos: balsa (ponto I) e manguezal (ponto II). Em cada ponto de coleta foram utilizados três tipos de coletores (1) garrafas PET transparentes, (2) garrafas PET verdes e (3) forro de PVC, com três réplicas cada. As sementes foram contadas e medidas a cada 45 dias e os dados ambientais mensurados a cada duas semanas. As espécies de ostras foram identificadas por teste genético (PCR multiplex) com individuos aleatoriamente selecionados por coleta. Os resultados indicaram que a captura de sementes foi influenciada significativamente pelo tipo de coletor, localização e periodo de coleta $(P<0,05$, MANOVA) com recrutamento significativamente maior no coletor de PVC $(P<0,05$, teste de Tukey). O recrutamento ocorreu durante todo ano, sugerindo reprodução mensal, contudo, os meses de menor pluviosidade e maior salinidade foram melhores para coletar sementes, enquanto o periodo chuvoso, com menor salinidade, favoreceu um crescimento superior. O local de coleta em interação com variáveis ambientais, principalmente salinidade, apresentou efeito significativo sobre a fixação e tamanho das sementes de maneira que o ponto II obteve melhores resultados de fixação e o ponto I sementes de maior tamanho. A análise genética identificou duas espécies nativas (Crassostrea gasar e Crassostrea rhizophorae) em ambos os pontos (I e II).

Palavras-chave: ostra do mangue, coleta de semente, variáveis ambientais.

\section{INTRODUCTION}

Oyster spat is the main raw material for oyster culture and can be purchased from specific hatcheries that produce spat, extracted directly from natural banks or obtained by using artificial collectors introduced in the natural environment for their recruitment. In mollusk culture, spat collection with artificial substrates is quite widespread and many traditional oyster producers, as in some regions of Italy, France, China and Japan, still depend to some degree on capturing spat from artificial substrates (MATTHIESSEN, 2001). Due to the difficulty and high cost of spat production in hatcheries, much of the culture of native oysters on the Brazilian coast depends on spats recruited from the natural 
environment using artificial collectors (PEREIRA et al., 2003).

Collectors are structures that are installed in the environment and used for settlement by oyster larvae and other encrusting organisms reported in water (CASTILHO-WESTPHAL et al., 2015). Nevertheless, to successfully obtain spat in a region, studies must be conducted about the reproductive period, the environmental conditions favorable to settlement, substrate preference, ideal depth for placing collectors, type of collector, angle of the collector sheets, shading, as well as the time of year of the occurrence of larvae apt for settlement (CHRISTO \& CRUZ, 2009).

In oyster culture, a variety of materials have been used for recruiting oyster spats in the natural environment, such as mollusk shells, mangrove roots, car tires, roof tiles, cement/asbestos sheets, granite, fiberglass, stainless steel, PET bottles and PVC ceiling sheets (LEE et al., 2012). BUITRAGO \& ALVARADO (2005) affirmed that many collectors tested were considered inadequate because they were expensive, difficult to build, made of non-durable materials (for example roof tiles) or because it was difficult to remove young oysters from the materials (as with the oyster shells). A substrate suitable for spats collection must be economically accessible, biologically acceptable and environmentally favorable (SONIAT \& BURTON, 2005). Collectors made of PET bottles and PVC boards are easily found, low cost, resistant and effective for recruiting spats (BUITRAGO \& ALVARADO, 2005).

Until now, we have no knowledge of data published about spat recruitment on the Amazon Macrotidal Mangrove Coast (AMMC) of Maranhão State. From this perspective, the purpose of this study was to determine the effectiveness of three types of collectors, made of low-cost recycled materials for spat recruitment and verify the period of year for spat recruitment, and environmental conditions that maximize recruitment. This is a way of contributing both to the scientific knowledge about the issue, and to the greater efficiency in spat collection to meet demands of producers in the region studied.

\section{MATERIALS AND METHODS}

The study was conducted in the estuary area of Raposa (Maranhão state) of northeastern Brazil using two locations: point I (Raft) and point II (Mangrove). At point I ( $2^{\circ} 25^{\prime} 40^{\prime \prime} \mathrm{S}$ and $\left.44^{\circ} 05^{\prime} 44^{\prime \prime} \mathrm{W}\right)$, collectors were disposed vertically on a floating raft used for oyster culture and remained submerged at both low and high tide, suffering strong influence from the currents. Each collector was tied at the far end to a 2-kilos weight to remain vertical. At point II $\left(2^{\circ} 25^{\prime} 06^{\prime}\right.$ 'S and $44^{\circ} 4$ ' $\left.43^{\prime \prime} \mathrm{W}\right)$, collectors were fixed vertically on the aerial mangrove roots, exposed to the air at low tide in an area protected from currents.

The experiment was carried out for 12 months. Three treatments (transparent PET collectors, green PET collectors and PVC sheets), with three repetitions of each were installed at points I and II. Each bottle collector (transparent PET and green PET) was composed of 21 half bottles, that were positioned in the collector with the convex part facing down and separated from each other with a $5 \mathrm{~cm}$ PVC spacer, each one having a total area of $15,693.72 \mathrm{~cm}^{2}$. The collector made of PVC (polyvinyl chloride ceiling sheets) had a total area of $14,422.8 \mathrm{~cm}^{2}$, and was composed of 21 sheets, which were also separated with $5 \mathrm{~cm}$ spacers. The total length of each collector was $120 \mathrm{~cm}$, and at the time of analysis each collector was divided into 3 depths (D1:0-40cm; D2: 41-80cm and D3: $81-120 \mathrm{~cm}$ ) (Figure 1).

Collectors remained 45 days in the water and were replaced for new ones at each sampling period. At each sampling, the fixed spats were counted, for collector and for each depth (D1; D2 and D3).

With the help of a digital caliper (WESTERN ${ }^{\circledR}$ ), the shell height was measured (inmm) for 50 spat per depth, 150 per type of collector, for a total of 2,700 individuals measured per sampling date. After the counting of the total number of spats, there was determined the density of spat fixation. This density was obtained by dividing the total number of spats on each sheet (PET or PVC) by their respective area, which was $686.8 \mathrm{~cm}^{2}$, for the PVC collector, and $747.32 \mathrm{~cm}^{2}$ for the PET bottles.

For the identification of oyster species at the recruitment points, genetic tests were performed on the individuals fixed in the collectors, randomly selected by sampling. This identification was performed by multiplex PCR of oysters of the genus Crassostrea, described by MELO et al. (2013).

Dissolved oxygen (mg $\left.\mathrm{L}^{-1}\right), \mathrm{pH}$, temperature $\left({ }^{\circ} \mathrm{C}\right)$, salinity (YSI Multiprobe 556MPS) and water transparency $(\mathrm{cm})$ (Secchi disc) were monitored every two weeks. For Chl- $a\left(\mathrm{mg} \mathrm{m}^{-3}\right)$ and suspended particulate matter (organic and inorganic fraction) $\left(\mathrm{mg} \mathrm{L}^{-1}\right)$, two liters of water were collected every two weeks at each point, which were stored and transported in a thermal tank to the laboratory. The determination of the Chl- $a$ concentration was performed by spectrophotometry using the JEFFREY \& HUMPHREY methodology (1975). The fractions 


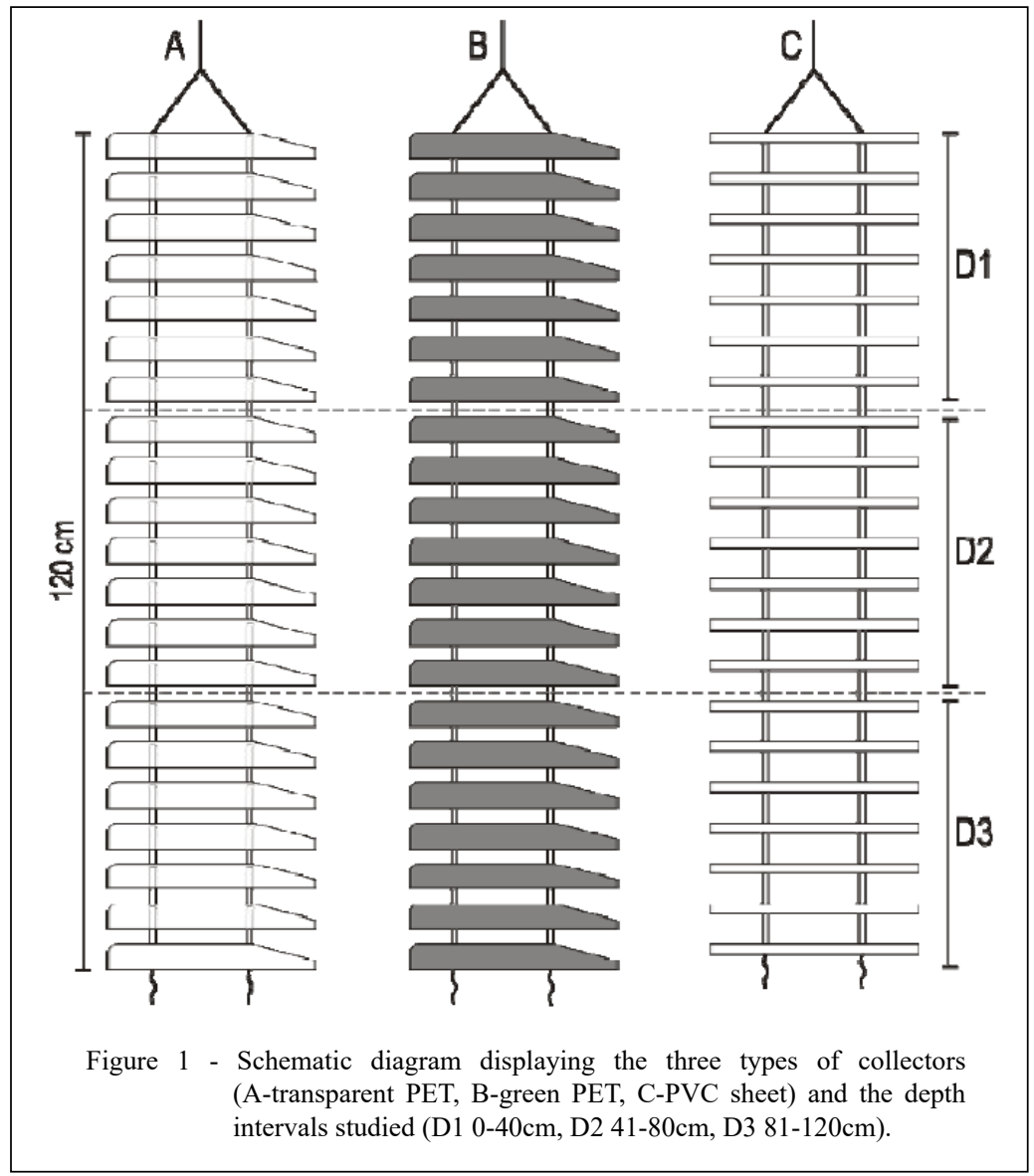

of total particulate matter (TPM), particulate organic matter (POM) and particulate inorganic matter (PIM) were determined according to the methodology described by CUBILLO et al. (2012). The data for rainfall for the municipality of Raposa was provided by the Núcleo de Geoprocessamento [Geoprocessing Center] of the Universidade Estadual do Maranhão [Maranhão State University].

For all the data, when distinct numbers were presented, normality was analyzed using the Kolmogorov-Smirnov test and homogeneity of variance using Cochran tests $(\mathrm{P}<0.05)$. The Student's $t$ test $(\mathrm{P}<0.05)$ was used to compare the average values of environmental variables (temperature, salinity, $\mathrm{pH}$, transparency, dissolved oxygen, chlorophyll $a$, total particulate matter, and organic and inorganic matter) between points I and II, and between the rainy and dry periods at each location. To evaluate the influence of factors (type of collector, location, period and depth) upon density and height of the spats, the Multifactorial Variance Analysis (MANOVA) and the Tukey test $(\mathrm{P}<0.05)$ were used. The data were analyzed using the Statistica version 7.0 (STATSOFT, 2004). Correlation between the biological parameters (spat density and height) and the environmental parameters were placed in evidence through the principal component analyses (PCA) which was carried out using the statistical software Palaeontological Statistics Past v.2.17c (HAMMER, 2012).

\section{RESULTS}

In relation to the environmental variables, it was reported that at point I (raft) the average values for temperature and salinity were significantly higher in the dry period, while the average concentrations of Chl- $a$ and total particulate matter, organic and inorganic, were significantly higher $(\mathrm{P}<0.05)$ in the rainy period. Concerning the seasonal variation at point II (mangrove), the average values for temperature, salinity and transparency were significantly higher in the dry period, while the variables Chl- $a$ and the fractions of TPM, POM and PIM were significantly higher in the rainy period $(\mathrm{P}<0.05)$ (Table 1$)$.

Refering to the variation between locations, it was reported that the variables temperature, salinity, transparency and dissolved oxygen were significantly higher at point $\mathrm{I}(\mathrm{P}<0.05)$, while the fractions of total 
Table 1 - Average and standard deviation of environmental variables referring to the rainy and dry periods for points I and II in the municipality of Raposa, Maranhão, Brazil. Value indicated with an asterisk indicates that it was significantly higher for the respective location and seasonal period indicated (Student $t$ test, $\mathrm{P}<0.05$ ). Where: TPM=total particulate matter; $\mathrm{POM}=$ particulate organic matter and PIM=particulate inorganic matter.

\begin{tabular}{|c|c|c|c|c|}
\hline \multirow[t]{2}{*}{ Variables } & \multicolumn{2}{|c|}{ 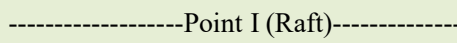 } & \multicolumn{2}{|c|}{-----------Point II (Mangrove)---------- } \\
\hline & Rainy & Dry & Rainy & Dry \\
\hline Temperature $\left({ }^{\circ} \mathrm{C}\right)$ & $29.0 \pm 0.3$ & $29.6 \pm 0.3^{*}$ & $28.8 \pm 0.5$ & $29.4 \pm 0.2^{*}$ \\
\hline Salinity & $33.1 \pm 1.8$ & $40.5 \pm 1.2^{*}$ & $31.7 \pm 1.6$ & $38.8 \pm 1.7^{*}$ \\
\hline $\mathrm{pH}$ & $7.6 \pm 0.1$ & $7.3 \pm 0.5$ & $7.5 \pm 0.2$ & $74 \pm 0.5$ \\
\hline Transparency $(\mathrm{cm})$ & $53.3 \pm 10.5$ & $64.1 \pm 6.3$ & $23.2 \pm 4.3$ & $32.5 \pm 4.2^{*}$ \\
\hline Dissolved oxygen $\left(\mathrm{mg} \mathrm{L}^{-1}\right)$ & $4.5 \pm 0.6$ & $5.1 \pm 0.7$ & $3.3 \pm 0.9$ & $4.3 \pm 0.6$ \\
\hline Total Chlorophyll $a\left(\mathrm{mg} \mathrm{m}^{-3}\right)$ & $11.1 \pm 2.2^{*}$ & $8.0 \pm 1.2$ & $12.4 \pm 2.1^{*}$ & $9.1 \pm 1.1$ \\
\hline TPM $\left(\mathrm{mg} \mathrm{L}^{-1}\right)$ & $56.5 \pm 6.6^{*}$ & $37.9 \pm 9.4$ & $71.4 \pm 12.5^{*}$ & $43.7 \pm 9.2$ \\
\hline POM $\left(\mathrm{mg} \mathrm{L}^{-1}\right)$ & $10.2 \pm 2.8^{*}$ & $7.1 \pm 1.7$ & $12.3 \pm 2.0^{*}$ & $6.9 \pm 1.8$ \\
\hline PIM $\left(\mathrm{mg} \mathrm{L}^{-1}\right)$ & $46.3 \pm 4.2^{*}$ & $30.9 \pm 7.8$ & $59.1 \pm 10.5^{*}$ & $36.7 \pm 7.8$ \\
\hline
\end{tabular}

particulate material (TPM) and inorganics (PIM) were significantly higher at point II $(\mathrm{P}<0.05)$. The monthly precipitation in the region studied varied from 0.4 to 296 millimeters, with accumulated amounts of 1.296 and $131.40 \mathrm{~mm}$ in the rainy and dry periods respectively.

The genetic identification analysis verified the existence of two native species of oysters in both points (I and II). Based on the evaluation of the agarose gel amplifications, was observed single band patterns with $718 \mathrm{bp}$ and double bands with $718 \mathrm{bp}$ and $377 \mathrm{bp}$, corresponding respectively to the species Crassostrea gasar and Crassostrea rhizophorae (Figure 2).

The principal components analysis indicated a distinction between the samples taken in the rainy period, in comparison to those in the dry period. At both points studied, the environmental variables salinity, temperature, transparency and dissolved oxygen had higher associations to the dry period, while precipitation, $\mathrm{pH}$, particle matter
(TPM, PIM and POM) and chlorophyll- $a$, were associated mainly to the rainy period (Figures 3 and 4). Concerning the behavior of biological variables (spat density and height), at point $I$ it was observed that the development was mainly associated to the physical and chemical variables that were correlated to the rainy period, mainly to density (Figure 3).

Meanwhile at point II, there was a slight trend towards higher values for spat height during the rainy period; although, unlike that observed at point $\mathrm{I}$, the values for density were more associated to the dry period, indicating a direct correlation, mainly for salinity (Figure 4).

During the period of the experiment, a total of 296,845 oyster were recruited, and of these 68,402 were fixed on the transparent PET bottles, 91,779 on the green PET bottles and 136,664 on the PVC sheet collectors.

Multifactorial variance analysis (Table 2) lists the main sources of variation, as well as the relations

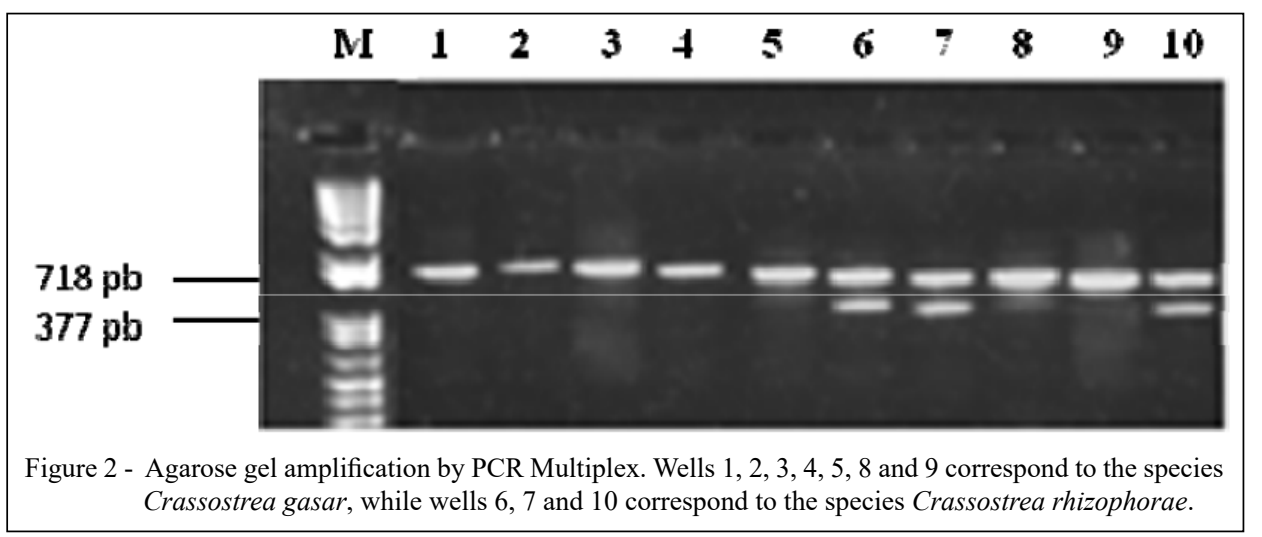

Ciência Rural, v.49, n.3, 2019. 


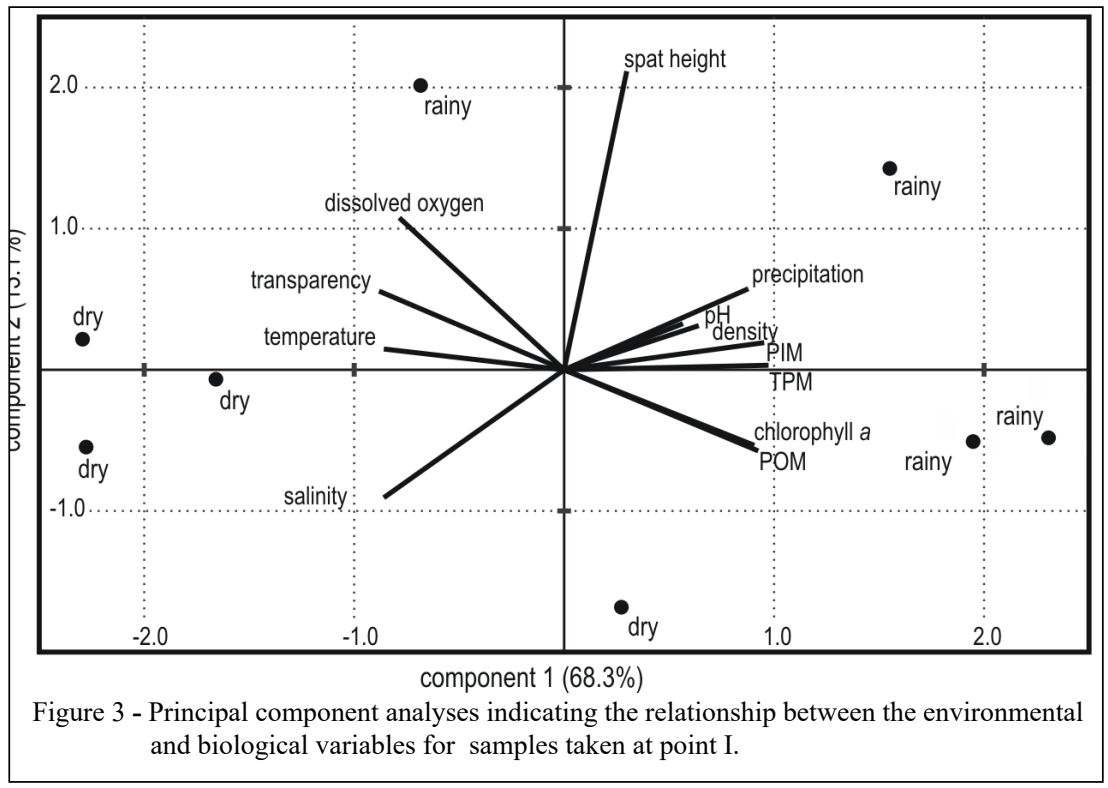

between the factors and their influence on the density of oyster recruitment per $\mathrm{cm}^{-2}$. In this way, we noted that the factors (type of collector, location and period) and their correlations, significantly influenced results of settlement $(\mathrm{P}<0.05)$. Depth and its correlations did not directly influence the rate of oyster settlement $(\mathrm{P}>0.05)$.

When the influence of the type of collector on the density of settlement was evaluated, a significant superiority of the collector made with PVC sheets over the collectors made of PET bottles was observed $(\mathrm{P}<0.05)$.

Among the collectors made from PET bottles, the color of the bottle significantly influenced spat capturing, obtaining $0.142 \pm 0.2$ spat $\mathrm{cm}^{-2}$ with the green bottle and $0.084 \pm 0.1$ spat $\mathrm{cm}^{-2}$ with the transparent bottle $(\mathrm{P}<0.05)$ (Figure 5A).

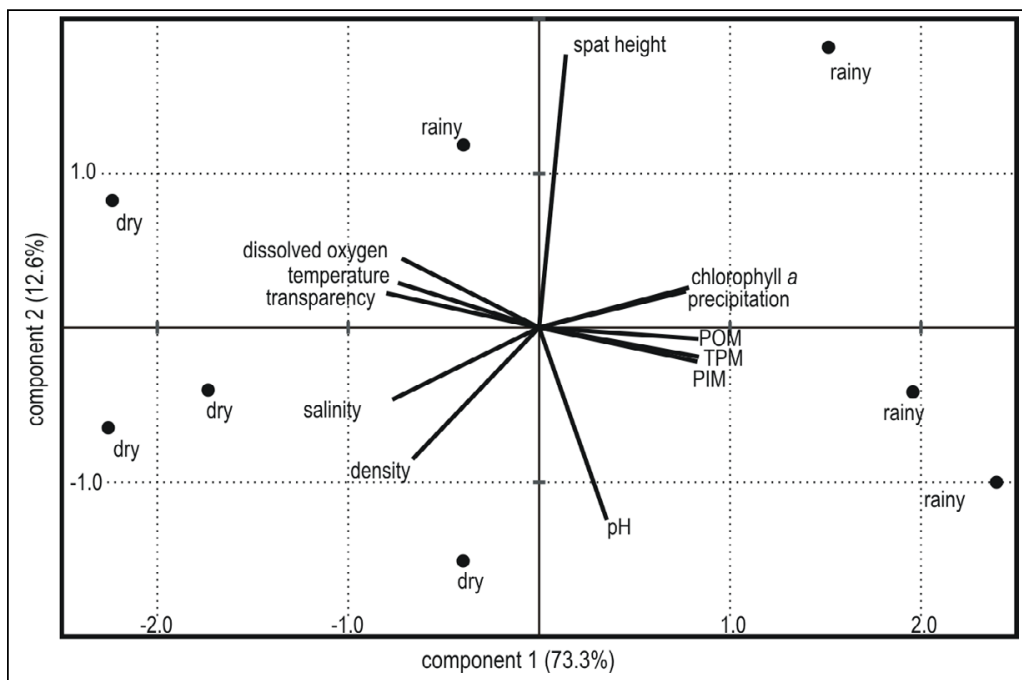

Figure 4 - Principal component analyses indicating the relationship between the environmental and biological variables for the samples taken at point II. 
Table 2 - Multifactorial Variance Analysis of density of oyster settlement (spat $\mathrm{cm}^{-2}$ ) as a function of collector type, depth, location, period and their respective interactions. FV: Source of Variation; SQ: Sum of squares; GL: Degree of liberty; QM: Squared Avg.; F: F calculated; $P$ : Value of p. ${ }^{*}$ Significant difference $(\mathrm{P}<0.05)$.

\begin{tabular}{|c|c|c|c|c|c|}
\hline FV & SQ & GL & QM & $\mathrm{F}$ & $\mathrm{P}$ \\
\hline Type & 0.942959 & 2 & 0.471479 & 65.71 & $0.000000^{*}$ \\
\hline Depth & 0.000769 & 2 & 0.000384 & 0.05 & 0.947841 \\
\hline Location & 4.794033 & 1 & 4.794033 & 668.14 & $0.000000^{*}$ \\
\hline Period & 3.893831 & 7 & 0.556262 & 77.53 & $0.000000^{*}$ \\
\hline Type x Depth & 0.006014 & 4 & 0.001504 & 0.21 & 0.933003 \\
\hline Type x Location & 0.986439 & 2 & 0.493220 & 68.74 & $0.000000^{*}$ \\
\hline Depth x Location & 0.001376 & 2 & 0.000688 & 0.10 & 0.908569 \\
\hline Type x Period & 1.107847 & 14 & 0.079132 & 11.03 & $0.000000^{*}$ \\
\hline Depth x Period & 0.120531 & 14 & 0.008609 & 1.20 & 0.275026 \\
\hline Location $\mathrm{x}$ Period & 4.509941 & 7 & 0.644277 & 89.79 & $0.000000^{*}$ \\
\hline Type $\mathrm{x}$ Depth x Location & 0.007033 & 4 & 0.001758 & 0.25 & 0.912508 \\
\hline Type x Depth x Period & 0.215087 & 28 & 0.007682 & 1.07 & 0.374256 \\
\hline Type $\mathrm{x}$ Location $\mathrm{x}$ Period & 1.253601 & 14 & 0.089543 & 12.48 & $0.000000^{*}$ \\
\hline Depth $\mathrm{x}$ Location $\mathrm{x}$ Period & 0.119616 & 14 & 0.008544 & 1.19 & 0.281952 \\
\hline Type $\mathrm{x}$ Depth $\mathrm{x}$ Location $\mathrm{x}$ Period & 0.202055 & 28 & 0.007216 & 1.01 & 0.461576 \\
\hline Error & 1.937294 & 270 & 0.007175 & & \\
\hline
\end{tabular}

The location also presented a significant variation, observing that, for the three types of collectors tested, there was a settlement rate significantly higher at point II $\left(0.260 \pm 0.2 \mathrm{spat} \mathrm{cm}^{-2}\right)$. Types of collectors did not influence the recruitment of oyster at point I $(\mathrm{P}>0.05)$; although, at point II the density of spats fixed in the PVC collectors was significantly higher $(\mathrm{P}<0.05)$ (Figure $5 \mathrm{~B})$.

In terms of the effect of period on the density of oyster recruited at the collectors tested, it was reported that at point I, there was a low spat fixation during the experiment, and no significant difference was registered $(\mathrm{P}>0.05)$. Meanwhile, at point II it was observed that the dry season, which included the period of August to January, was significantly superior to the rainy season, with samplings conducted between February and July $(\mathrm{P}<0.05)$ (Figure $5 \mathrm{C})$.

In relation to the biometric analysis of the oyster recruited, multifactorial analysis of variance indicated that all the sources of first order variation (type, depth, location and period) have a significant influence on the size of the spats obtained $(\mathrm{P}<0.05)$. Nevertheless, the correlations of depth with the other factors did not significantly influence $(\mathrm{P}>0.05)$ the height of the oysters recruited (Table 3).

The average size of the oysters recruited in the region studied was significantly higher in the green PET collectors $(11.4 \pm 5 \mathrm{~mm}$ ) (Figure 6A). In relation to the location, it was reported that the average spat height at location I $(14.57 \pm 2.8 \mathrm{~mm})$ was significantly higher than that of the spats collected at location II $(6.97 \pm 2.0 \mathrm{~mm})$. Types of collectors did not influence the growth of the spats at location II, nevertheless, at location I, the height of the spats in the green PET collector was significantly higher $(\mathrm{P}<0.05)$ (Figure 6B).

Figure $6 \mathrm{C}$ indicates a direct relationship between the shell height and increased depth, so, the height of the oysters recruited at depth 1 $(10.16 \pm 4.2 \mathrm{~mm})$ was significantly lower $(\mathrm{P}<0.05)$ than the spats settled at depths $2(11.07 \pm 4.4 \mathrm{~mm})$ and 3 $(11.23 \pm 4.1 \mathrm{~mm})$. When the effect of period and location on oysters size was evaluated, it was noted that during the entire experiment, the spats fixed at location I had a significantly higher shell height $(\mathrm{P}<0.05)$. At location I, the spats recruited were significantly higher at the $3 \mathrm{rd}$ and 4 th samplings $(17.9 \pm 1.6 \mathrm{~mm}$ and $18.4 \pm 3.3 \mathrm{~mm}$, respectively) and, at location II, at the 3rd samplings $(11.3 \pm 1.8 \mathrm{~mm})(\mathrm{P}<0.05)$, both of which were in the rainy period (Figure $6 \mathrm{D}$ ).

\section{DISCUSSION}

In this study, the average density of oyster spats varied from 0.002 to 0.067 spats $\mathrm{cm}^{-2}$ at location I (raft), and from 0.049 to 0.612 spats $\mathrm{cm}^{-2}$ at location II (mangrove). Similar results to that from point II were obtained by BUITRAGO \& ALVARADO (2005), 


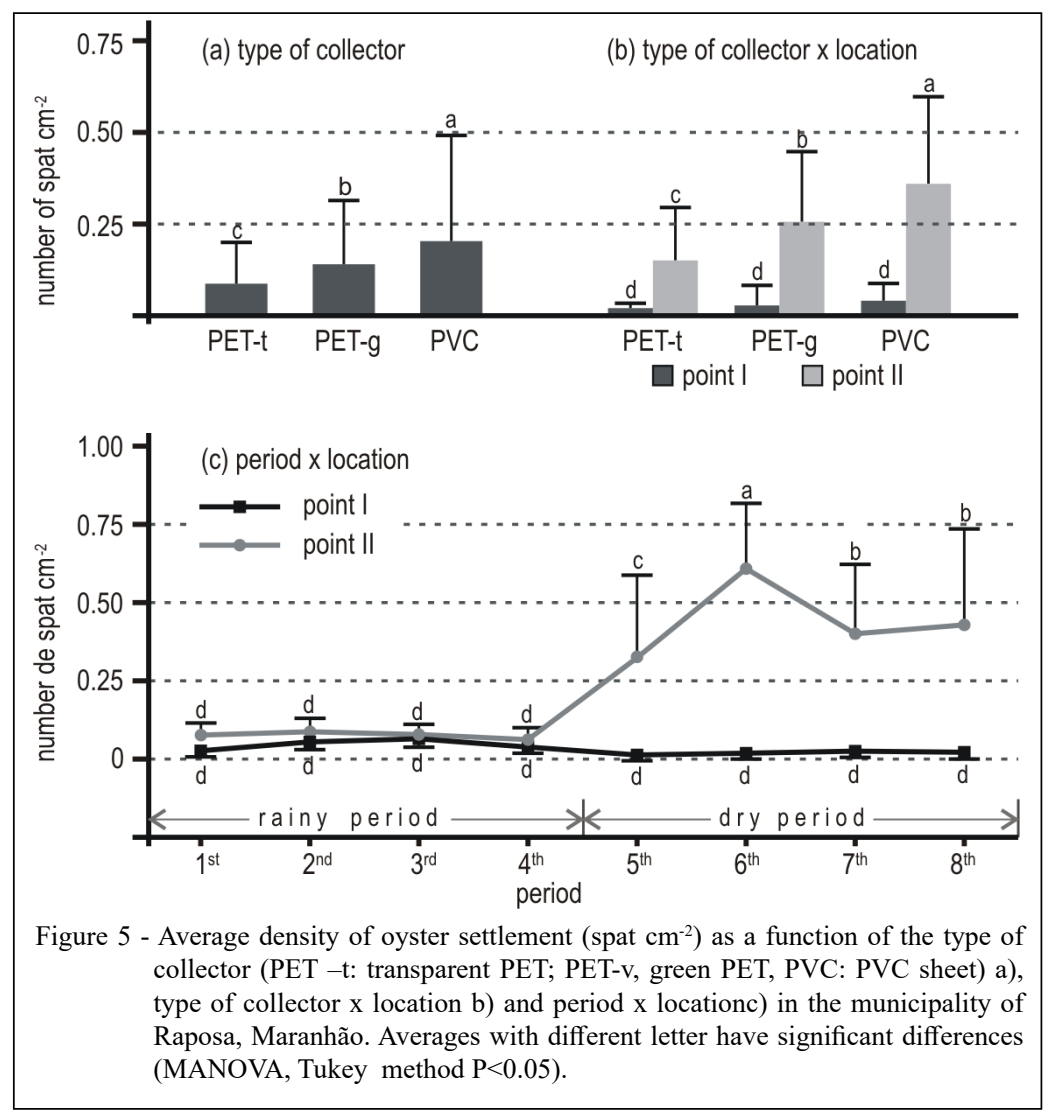

who studying larval settlement for C. rhizophorae in Venezuela, recorded amounts oscillating from 0.004 to 0.149 spats $\mathrm{cm}^{-2}$ and by GARDUNHO et al.(2012), in Pará State, who observed that the average density of spats of a non-identified oyster (Crassostrea sp.) varied from $(0.16$ a 0.75$)$ and $(0.074$ to 1.64$)$ spats $\mathrm{cm}^{-2}$ in collectors made of half and whole PET bottles respectively.

The principal component analyses revealed that at point I the density of oyster recruited was highly correlated to environmental variables associated to the rainy period $(\mathrm{pH}$, precipitation, TPM, POM and PIM) (Figure 3). These correlations indicated that at this location, there was a higher settlement of oyster in the rainy period than in the dry period; although, with values that do not differ significantly (Figure 5C). Collectors at this location remained immersed during the entire sampling period, which may have favored the higher recruitment of other organisms, with an abundance of cirripedia (barnacles), mainly in the dry period. Interspecific competition, especially from barnacles, probably had a negative effect on the settlement of oyster at point I, particularly in the dry period when, normally, according to PAIXÃO et al. (2013), there are peaks of egg laying of the native oyster Crassostrea gasar.

At point II, collectors were immersed in the high tide and emerged at low tide. This exposure to the air, naturally caused by the tidal cycle, reduced the encrustation of competitors, favoring a higher oyster settlement. It was also observed through the principal component analyses (PCA) that the values of density recruited at this location were more related to the dry period, indicating a direct correlation, mainly with salinity, apparently as a regulatory factor for the higher settlement of oysters in the collectors of this location (Figure 4). PAIXÃO et al. (2013) suggested that the increased salinity during the dry period was a fundamental factor in the release of the gametes of C. gasar and, consequently, of greater settlement, corroborating the results of this study.

The empty spaces on the surface of the collectors are potential locations to oyster larval settlement, nevertheless, the recruitment of other organisms can create spatial competition. Studies conducted by NERY (2008) reveal that cirripedia 
Table 3 - Multifactorial analysis of variance of spat shell height $(\mathrm{mm})$ in relation to type of collector, depth, location, period and its respective interaction. FV: Source of Variation; SQ: Sum of squares; GL: Degree of liberty; QM: Squared Average; F: F calculated; $P$ : Value of $\mathrm{p}$. ${ }^{*}$ Significant difference $(\mathrm{P}<0.05)$.

\begin{tabular}{|c|c|c|c|c|c|}
\hline FV & SQ & GL & QM & $\mathrm{F}$ & $\mathrm{P}$ \\
\hline Type & 53.41 & 2 & 26.70 & 7.18 & $0.000920^{*}$ \\
\hline Depth & 80.26 & 2 & 40.13 & 10.78 & $0.000031^{*}$ \\
\hline Location & 5696.69 & 1 & 5696.69 & 1530.78 & $0.000000^{*}$ \\
\hline Period & 1617.57 & 7 & 231.08 & 62.09 & $0.000000^{*}$ \\
\hline Type x Depth & 4.62 & 4 & 1.15 & 0.31 & 0.870953 \\
\hline Type $\mathrm{x}$ Location & 85.73 & 2 & 42.86 & 11.52 & $0.000016^{*}$ \\
\hline Depth x Location & 5.76 & 2 & 2.88 & 0.77 & 0.462291 \\
\hline Type x Period & 119.59 & 14 & 8.54 & 2.30 & $0.005493^{*}$ \\
\hline Depth $x$ Period & 36.7 & 14 & 2.62 & 0.70 & 0.769545 \\
\hline Location $\mathrm{x}$ Period & 214.05 & 7 & 30.58 & 8.22 & $0.000000^{*}$ \\
\hline Type x Depth x Location & 4.75 & 4 & 1.19 & 0.32 & 0.865242 \\
\hline Type x Depth x Period & 41.3 & 28 & 1.47 & 0.40 & 0.997694 \\
\hline Type $\mathrm{x}$ Location $\mathrm{x}$ Period & 174.52 & 14 & 12.47 & 3.35 & $0.000055^{*}$ \\
\hline Depth $\mathrm{x}$ Location $\mathrm{x}$ Period & 38.18 & 14 & 2.73 & 0.73 & 0.740490 \\
\hline Type $\mathrm{x}$ Depth $\mathrm{x}$ Location $\mathrm{x}$ Period & 43.42 & 28 & 1.55 & 0.42 & 0.996458 \\
\hline Error & 1004.79 & 270 & 3.72 & & \\
\hline
\end{tabular}

(barnacles) are strong competitors of the oysters, mainly in the initial colonization phase. There is evidence that barnacles can also remove the oyster spats from the substrate (OSMAN et al., 1989). BUITRAGO \& ALVARADO (2005) limited the encrusting organisms by exposing the collectors out of the water for at least 3 hours each week and suggested that studies should be done to determine the effectiveness of different periods of emersion of the collectors.

Results indicated an oyster recruitment throughout the year, suggesting that these individuals reproduce during all months, although, the higher densities obtained were registered in the dry period (Figure 5C). Studies with $C$. rhizophorae and $C$. brasiliana in various coastal regions of the Brazilian northeast and southeast indicated continuous reproduction throughout the year, with peak egg lying in warmer periods (NASCIMENTO \& LUNETA, 1978; SILVA \& ABSHER, 1996).

According to PAIXÃO et al. (2013), increase in the frequency of mature oysters during the rainy and rainy-dry transition periods (which have low salinity) may be related to the higher concentrations of organic matter reported in the water of the Amazon region during this period (DITTMAR \& LARA, 2001). PAIXÃO et al. (2013) also suggested that the suspended organic matter is necessary for gonadal maturation of the oyster $C$. gasar, given that gamete production requires considerable energy input (LUNETTA \& GROTTA, 1982). These results corroborated the data obtained at point II, given that concentrations of particulate organic matter and of Chl- $a$ were significantly higher in the months of greater rainfall and of lower oyster settlement, suggesting that the gonadal maturation of adult oysters occurred mainly in this period. With the decreased rains, there was a substantial increase of spats attached to collectors at point II and at the roots of the surrounding mangrove.

Studies have reported that oysters have different settlement behavior on different surfaces (LEE et al., 2012; NALESSO et al., 2008), corroborating results obtained from point II, where it was reported that the type of artificial substrate significantly influenced oyster recruitment.

In this study, it was reported that, despite the superiority of the PVC collector for recruitment, the extraction of the spats from the collector sheets, after 45 days of immersion, was impeded by the low flexibility of the PVC sheets, causing breakage of the lower valve. However, in the PET bottle collectors, the removal of the spats was facilitated by the flexibility of the material, agreeing with BUITRAGO \& ALVARADO (2005). According to HOLLIDAY et al. (1993) the artificial collectors should not only 
facilitate the settlement and retention of the spat, but also allowed the collection of spats without damaging them. The same authors emphasized that it is also important to be able to collect the spats without damaging the collectors.

Results obtained here, suggested that the larva at the end of the larval cycle select substrates in shadows for settlement, which would help to explain the greater density of spats at location II (shaded by the presence of surrounding mangrove trees). For the same reason, the higher densities were obtained at the PVC sheet collectors, followed by the green PET bottles and finally the transparent PET bottles. According to MONTOYA \& MADRIZ (1986), the color and design of the oyster spat collectors influence larval settlement and the internal area of the collector is the most suitable location for settlement. Oyster larva has a negative phototropic behavior and during the pediveliger phase they are sensitive to light, preferring protected substrates in shadows for settlement (CASTILHO-WESTPHAL et al., 2015).

In this study, no significant difference was observed in the density of spats fixed at the three depth intervals (D1: 0-40cm; D2: $41-80 \mathrm{~cm}$ and D3: $81-120 \mathrm{~cm}$ ), suggesting that, for the region studied, $120 \mathrm{~cm}$ long collectors can be used. According to PILLAY (1990), the spats can be fixed over a large depth range. ANGELL (1986) revealed that the recruitment of $C$. rhizophorae decreased significantly after $100 \mathrm{~cm}$ of depth at Laguna de Restinga in Venezuela. Meanwhile, the study conducted by BUITRAGO \& ALVARADO (2005) reported that the spat density of $C$. rhizophorae settled on the PET bottle collectors at Isla Margarita, Venezuela, was high to a depth of $190 \mathrm{~cm}$.

In this study, it was reported that the types of collectors tested did not influence the growth of oyster recruited at point II, contrasting with the results obtained for point I, where significantly more oyster growth was found in the green PET collector. HOLLIDAY et al. (1993) evaluated the effectiveness of 10 artificial collectors, and found that higher spat growth was reported in collectors that had a lower density of oysters settled, and thus suggest that the competition for food probably increased with the density.

This study reported the highest spat growth at point I, where there was lower spat density; however, with greater inter-specific competition, while at point II, lower growth and higher density of spats was found (greater intraspecific competition) (Figure 6B and 6D). Thus, it was found that the growth of spats can also be associated to feeding. In this case, there was no significant difference between the concentrations of Chl- $a$ and particulate organic matter between the points studied; although, the higher growth of the spats at point I can be explained by the fact that the collectors were continuously immersed, allowing the spats to continuously filter food, while at point II the spats fed with lower frequency, as a consequence of the oscillation of the tides. This condition can explain the significant growth of the spats at depth 2 and 3, of between 41 and $120 \mathrm{~cm}$, mainly due to the results obtained from location II, given that they remained less time out of the water.

In relation to the seasonal period, results indicated that the higher average values for shell height were recorded in the rainy period, coinciding with the greater availability of food in the water (Chl- $a$ and POM). Nevertheless, the growth of the spats in the rainy period may not have been higher due to the high concentration of particulate organic matter in the water in this period, mainly at location II, where significantly higher fractions are registered. The higher occurrence of the particulate matter in suspension in this location was also revealed by means of lower transparency of water. According to FERREIRA \& MAGALHÃES (2004), bivalves are filtering organisms and ingest a high quantity of organic and inorganic detritus together with their food (which is mainly microalgae), considering that they do not have the ability to select the food. As a consequence of this behavior, the oyster recruited in this study tend to spend a lot of energy on food assimilation, given that most of the particulate matter belongs to the inorganic fraction, thus affecting spat growth.

Until this study, there was no information in the literature about the efficiency of artificial collectors for obtaining oyster spats on the Amazon Macrotidal Mangrove Coast of Maranhão State. Results presented here, especially from point II showed that the spats extracted from the collectors can help to supply part of the demand for spats in the region; although, the difficulty resides in the separation of species with potential for cultivation still as spats.

In the present research, the Multiplex PCR was able to identify the species Crassostrea gasar and Crassostrea rhizophorae in the same study area. The data reported are in agreement with other researches that show that in the Brazilian estuaries there are two or more species of oysters of the genus Crassostrea (LAPÈGUE et al., 2002; PIE et al., 2006; GARDUNHO et al., 2012; LOPES et al., 2018). The knowledge of the native oyster species to be recruited is fundamental 


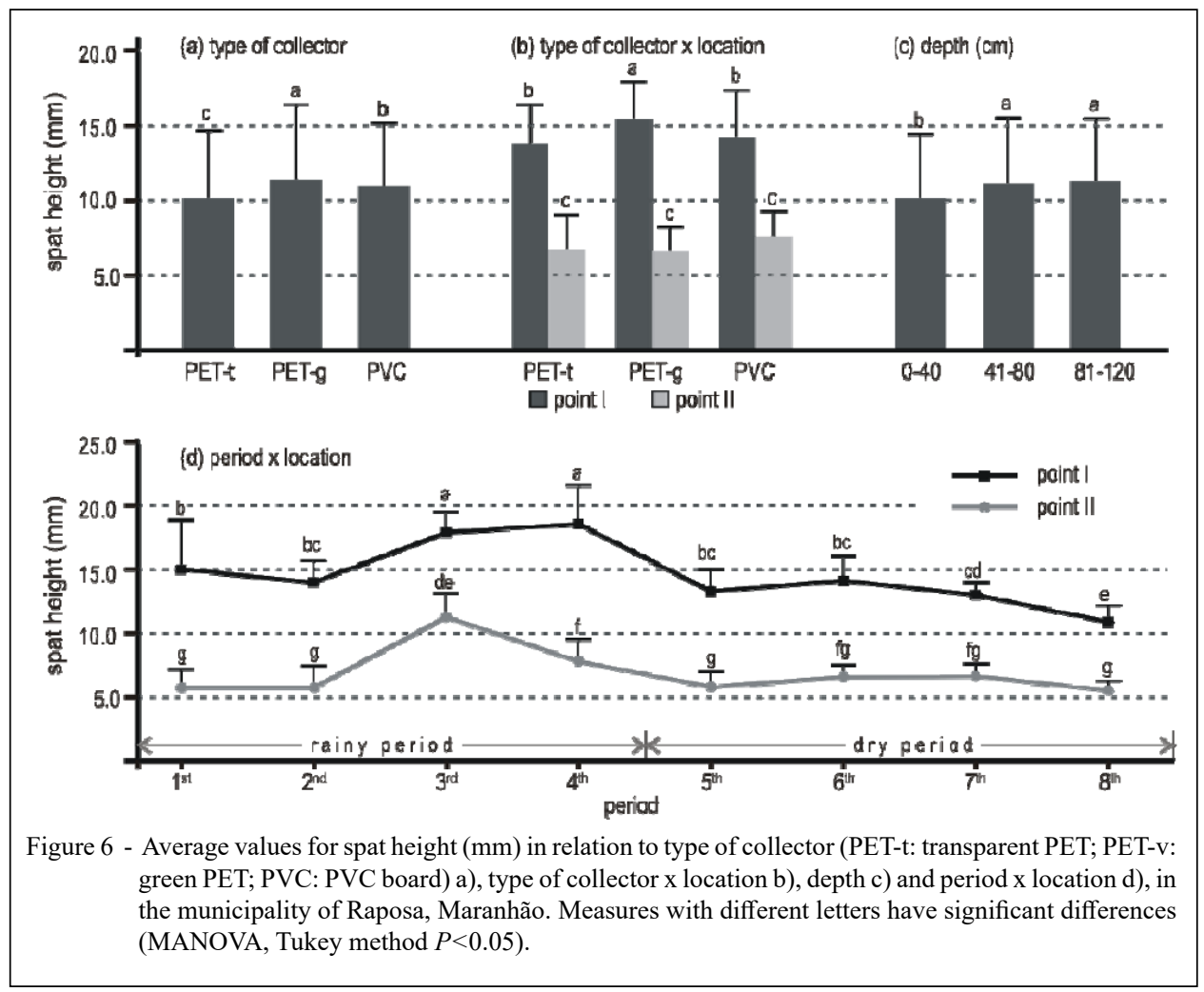

for an adequate management of this resource for both fishing and aquaculture (MELO et al., 2013).

It is thus suggested that future studies of recruitment in Maranhão identify the populations by means of genetic analysis, to focus on the collection of oysters of the suitable species and also improve the culture systems. According to GALVÃO et al. (2009), studies of genetic populations and of genetic improvement should help reduce current impediments to native oyster cultivation on the Brazilian coast.

According to the results obtained in the present study it was reported that one PVC collector $\left(\right.$ area $=14,422.8 \mathrm{~cm}^{2}$ ) recruited approximately 2,850 spats, with a medium heigh of $6.61 \mathrm{~mm}$ at each 45 days. Based on this data, an oyster productor could have a final crop of approximately 1,700 oysters (142 dozens), if the survival was $60 \%$.

\section{CONCLUSION}

The collectors used recruited two species of native oysters, Crassostrea gasar and Crassostrea rhizophorae. The collector made of PVC sheets was the most efficient for obtaining spats; although, the low flexibility of this substrate made it difficult to extract the individuals. The point II (mangrove) and the type of collector of PVC, favored shading and were more effective to oyster recruitment, mainly on dry season. The dry period was the most propitious for oyster recruitment, while the rainy period, when there is lower salinity and greater food availability (POM and Chl- $a$ ), was more favorable for the growth of these individuals.

In relation to depth, it is possible to install collectors at any depth within the interval studied $(0-120 \mathrm{~cm})$. The daily exposure of the collectors to the air, naturally offered by the tidal cycle, reduced the ratio of undesirable organisms and maximized the oyster recruitment. Otherwise, the collectors maintained continuously immersed had greater fixation of undesirable organisms, which may have negatively affected oysters recruitment.

\section{ACKNOWLEDGEMENTS}

We thank the members of the NUMAR Laboratory - IFMA and the FISIOMAR Laboratory - UEMA, for the support provided during the realization of this study; the graduate program in Recursos Pesqueiros e Aquicultura at the Universidade Federal Rural de Pernambuco (UFRPE), to the Instituto Federal de 
Educação, Ciência e Tecnologia do Maranhão, Campus São Luís Maracanã and the FAPEMA for the financial support (Process 01857/2012 and 00196/2012).

\section{BIOETHICS AND COMMITTEE APROVAL}

\section{BIOSSECURITY}

The study did not require the approval of an institutional ethics committee, since the researh was developed with oysters (bivalve mollusks), not falling under Art. 2 of Law 11.974 of October 8, 2008: "The provisions of this Law apply the animals of the species classified as phylum Chordata, subphylum Vertebrata, observing the environmental laws".

\section{DECLARATION OF CONFLICT OF INTERESTS}

The authors declare no conflict of interest. The founding sponsors had no role in the design of the study; in the collection, analyses, or interpretation of data; in the writing of the manuscript, and in the decision to publish the results.

\section{AUTHORS' CONTRIBUTIONS}

The authors contributed equally to the manuscript "Recruitment of oyster in artificial collectors on the Amazon macrotidal mangrove coast". All authors critically revised the manuscript and approved of the final version.

\section{REFERENCES}

ANGELL, C.L. The biology and culture of tropical oysters, 1986.

ICLARM Studies and Reviews 13. In: INTERNATIONAL CENTER FOR LIVING AQUATIC RESOURCES, 13, 1986, Manila. The International Development Research Centre of Canada through ICLARM's Selective Information Service Project, 1986. v.13, p.18.

BUITRAGO, E.; ALVARADO, D. Highly efficient oyster spat collector made with recycled materials. Aquacultural Engineering, v.33, p.63-72, 2005. Available from: <http:// doi:10.1016/j.aquaeng.2004.11.003>. Accessed: May, 14, 2018. doi: doi: 10.1016/j.aquaeng.2004.11.003.

CASTILHO-WESTPHAL, G.G. et al. Gonad morphology and reproductive cycle of the mangrove oyster Crassostrea brasiliana (Lamarck, 1819) in the Baia de Guaratuba, Paraná, Brazil. ActaZoologica (Stockholm), v.96, p.99-107, 2015. Available from: $<\mathrm{http}: / / 10.1111 /$ azo.12055>. Accessed: May, 14, 2018. doi: 10.1111/azo.12055.

CHRISTO, S.W.; CRUZ, E. Recruitment of oysters and Barnacles (cirripedia) in na artificial channel in Pontal do Sul, Pontal do Paraná, Paraná. Publicatio UEPG Biological and Health Sciences, v.15, n.2, p.43-48, 2009. Available from: <http://dx.doi. org/10.5212/publicatio\%20uepg.v15i2.1869>. Accessed: May, 14, 2018. doi:10.5212/Publ.Biologicas.v.15i2.043048.

CUBILLO, A.M. et al. Influence of stocking density on growth of mussels (Mytilus galloprovincialis) in suspended culture. Aquaculture, v.342-343, p.103-111, 2012. Available from: $<$ https://doi.org/10.1016/j.aquaculture.2012.02.017>. Accessed: May, 14, 2018. doi: 10.1016/j.aquaculture.2012.02.017.
DITTMAR, T.; LARA, R.J. Driving forces behind nutrient and organic matter dynamics a mangrove tidal creek in north Brazil. Estuarine, Coastal and Shelf Science, v.52, p.249-259, 2001. Available from: $<$ https://doi.org/10.1006/ecss.2000.0743>. Accessed: May, 14, 2018. doi: $10.1006 /$ ecss.2000.0743

FERREIRA, J.F.; MAGALHAES, A.R.M. Cultivo de Mexilhões. In: POLI, C.R.; et al.(eds.). Aquicultura: experiências brasileiras. Florianópolis: Multitarefa, 2004. p.221-250.

GALVÃO, M.S.N. et al. Performance of juvenile culture of the mangrove oyster Crassostrea sp. in suspended lanterns in subtidal zone of the cananéia estuary and itaguá bay, ubatuba (São Paulo state, Brazil). Boletim do Instituto de Pesca, v.35, n.3, p.401-411, 2009. Available from: <https://www.pesca.sp.gov.br/35_3_401411.pdf >. Accessed: May, 14, 2018.

GARDUNHO, D.C.L. et al. Settlement of an unidentified oyster (Crassostrea) and other epibenthos on plastic substrates at a northern Brazilian mangrove island. Brazilian Journal of Aquatic Science and Technology, v.16, n.1, p.41-51, 2012. Available from: <http://pdfs. semanticscholar.org/28a8/bae25ecdb970b6a13ac32244746ba14508c5. pdf $>$. Accessed: May, 14, 2018.

HAMMER, Ø. (2012): PAST. Paleontological Statistics. Version 2.17. Reference manual. Natural History Museum, University of Oslo.

HOLLIDAY, J.E. et al. Effects of stocking density on juvenile Sydney rock oysters, Saccostrea commerciallis (Iredale and Roughley), in cylinders. Aquaculture, v.109, p.13-26, 1993. Available from: $<$ https://doi.org/10.1016/0044-8486(93)90482-E $>$. Accessed: May, 14, 2018. doi: 10.1016/0044-8486(93)90482-E.

JEFFREY, S.W.; HUMPHREY, G.F. New spectrophotometric equations for the determining chlorophylls a, b, c1, and c2 in higher plants, algae and natural phytoplankton. Biochemie und Physiologie der Pflanzen, v.167, p.191-194, 1975. Available from: $<$ https://doi.org/10.1016/S0015-3796(17)30778-3>. Accessed: May, 14, 2018. doi: 10.1016/S0015-3796(17)30778-3.

LAPĖGUE, S. et al. Trans-Atlantic distribution of a mangrove oyster species revealed by $16 \mathrm{~S} \mathrm{mtDNA}$ and karyological analyses. The Biological Bulletin, v.202, p.232-242, 2002. Available from: <https:// pdfs.semanticscholar.org/b0d3/3380f74dadce7ab4ee93c5dcd0ee9ed8 94d0.pdf $>$. Accessed: May, 14, 2018. doi: 10.2307/1543473.

LEE, K.M. et al. Effects of tidal elevation and substrate type on settlement and postsettlement mortality of the sydney rock oyster, Saccostrea glomerata, in a mangrove forest and on a rocky shore. Journal of Shellfish Research, v.31, n.4, p.1043-1050, 2012. Available from: <https://doi.org/10.2983/035.031.0416>. Accessed: May, 14, 2018. doi: 10.2983/035.031.0416.

LOPES, R.G.P.S. et al. Molecular identification of native oysters on the coast of Maranhão, Brazil. Boletim do Instituto de Pesca, v.44, n.4, e377, 2018. Available from: <https://www.pesca.sp.gov.br/9 MOLECULAR-IDENTIFICATION-OF-NATIVE-OYSTERSON-THE-COAST-OF-MARANHAO-BRAZIL.html>. Accessed: Oct. 18, 2018. doi: 10.20950/1678-2305.2018.44.4.377.

LUNETTA, J.E.; GROTTA, M. Influência de fatores exógenos e endógenos sobre a reprodução de moluscos marinhos. Boletim de Fisiologia Animal, v.6, p.191-204, 1982.

MATTHIESSEN, G.C. Oyster culture. Blackwell Science Ltd.:Oxford, 2001.

Ciência Rural, v.49, n.3, 2019. 
MELO, M.A.D. et al. Multiplex species-specific PCR identification of native and non-native oysters (Crassostrea) in Brazil: a useful tool for application in oyster culture and stock management. Aquaculture International, v.21, p.1325-1332, 2013. Available from: <https://link.springer.com/content/ pdf/10.1007\%2Fs10499-013-9635-8.pdf>. Accessed: May, 14, 2018. doi: 10.1007/s10499-013-9635-8.

MONTOYA, J.A.; MADRIZ, E.Z. Cultivo de Crassostrea rhizophorae (Bivalvia: Ostreidae). I: El uso de la lámina para techo como colector de "semillas". Revista Latino Americana de Acuicultura, 28: 29-32, 1986.

NALESSO, R.C. et al. Oyster spat recruitment in Espírito Santo estate, Brazil, using recycled materials. Brazilian Journal of Oceanography, v.56, n.4, p.281-288, 2008. Available from: <http:// dx.doi.org/10.1590/S1679-87592008000400003>. Accessed: May, 14, 2018. doi: 10.1590/S1679-87592008000400003.

NASCIMENTO, I.A.; LUNETTA, J.E. Ciclo sexua da ostra de mangue e sua importância para o Cultivo. Boletim de Zoologia da Universidade de São Paulo, v.2, p.63-98, 1978. Available from: <http://www.scielo.br/ scielo.php?script $=$ sci nlinks \& ref $=000090 \&$ pid $=$ S 1519 $6984201100040001200027 \& \operatorname{lng}=\mathrm{en}>$. Accessed: May, 14, 2018.

NERY, P.P.C.F. et al. Ecological recruitment and succession of the incrustant macrofauna in substrates at the port of Recife - PE, Brazil. Revista Brasileira de Engenharia de Pesca, v.3, n.1, p.5161, 2008. Available from: <http://ppg.revistas.uema.br/index.php/ REPESCA/article/viewFile/63/61>. Accessed: May, 14, 2018.

OSMAN, R.W. et al. Effects of resident species on cruitment into a community - larval settlement versus postsettlement mortality in theoyster Crassostrea virginica. Marine Ecology Progress Series, v.54, p.61-73, 1989. Available from: <http://www.jstor.org/ stable/24837814>. Accessed: May, 14, 2018.
PAIXÃO, L. et al. Effects of salinity and rainfall on the reproductive biology of the mangrove oyster (Crassostrea gasar): Implications for the collection of broodstock oysters. Aquaculture, v.6, n.12, p.380-383, 2013. Available from: <https://doi.org/10.1016/j. aquaculture.2012.11.019>. Accessed: May, 14, 2018. doi: 10.1016/j.aquaculture.2012.11.019.

PEREIRA, O.M.et al. Growth curve estimation of the oyster Crassostrea brasiliana in the mangrove and a proposal to their sustainable extraction in Cananéia estuary, SP, Brazil. Boletim do Instituto de Pesca, v.29, p.19-28, 2003. Available from: <https:// www.pesca.sp.gov.br/Pereira29(1).PDF>. Accessed: May, 14, 2018.

PIE, M.R. et al. A simple PCR-RFLP method for the discrimination of native and introduced oyster species (Crassostrea brasiliana, $C$. rhizophorae and C. gigas; Bivalvia: Ostreidae) cultured in Southern Brazil. Aquaculture Research, v.37, p.1598-1600, 2006. Available from: $<$ https://doi.org/10.1111/j.1365-2109.2006.01591.x >. Accessed: May, 14, 2018. doi: 10.1111/j.1365-2109.2006.01591.x.

PILLAY, T.V.R.Aquaculture, principles and practices. London: Blackwell Science, 1990

SILVA, B.G.; ABSHER, T.M. Variação temporal de larvas de ostras do gênero Crassostrea SACCO,1897 (Ostreoida:Ostreidae) na Baía de Paranaguá, Paraná. Arquivos de Biologia e Tecnologia, v.39, n.4, p.903-910, 1996.

STATSOFT. STATISTICA(data analysis software system), version 7. 2004. Available from: $<$ https://www.statsoft.com $>$. Accessed: May, 14, 2018.

SONIAT, T.; BURTON, G.M. A comparison of the effectiveness of sandstone and limestone as cultch for oysters, Crassostrea virginica. Journal of Shellfish Research, v.24, n.2, p.483485, 2005. Available from: <https://doi.org/10.2983/07308000(2005)24[483:ACOTEO]2.0.CO;2>. Accessed: May, 14, 2018. doi: 10.2983/0730-8000(2005)24[483:ACOTEO]2.0.CO;2. 